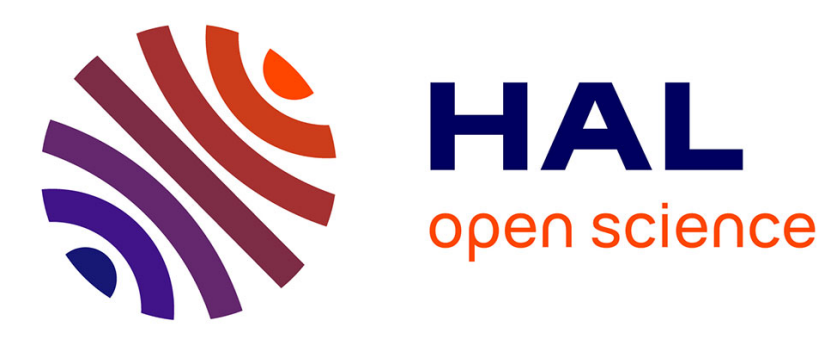

\title{
A Context-Based Awareness Mechanism for Mobile Cooperative Users
}

Manuele Kirsch-Pinheiro, Marlene Villanova-Oliver, Jerôme Gensel, Hervé Martin

\section{- To cite this version:}

Manuele Kirsch-Pinheiro, Marlene Villanova-Oliver, Jerôme Gensel, Hervé Martin. A Context-Based Awareness Mechanism for Mobile Cooperative Users. 2004, pp.9-10. hal-00120282

\section{HAL Id: hal-00120282 \\ https://hal.science/hal-00120282}

Submitted on 13 Dec 2006

HAL is a multi-disciplinary open access archive for the deposit and dissemination of scientific research documents, whether they are published or not. The documents may come from teaching and research institutions in France or abroad, or from public or private research centers.
L'archive ouverte pluridisciplinaire HAL, est destinée au dépôt et à la diffusion de documents scientifiques de niveau recherche, publiés ou non, émanant des établissements d'enseignement et de recherche français ou étrangers, des laboratoires publics ou privés. 


\title{
A Context-Based Awareness Mechanism for Mobile Cooperative Users
}

\author{
Manuele Kirsch-Pinheiro*, Marlène Villanova-Oliver", Jérôme Gensel*, Hervé Martin \\ * Laboratoire LSR - IMAG, BP 72 - 38402 Saint Martin d'Hères Cedex, France \\ \{kirsch, villanov, gensel, martin\}@imag.fr
}

\begin{abstract}
This paper presents a context-based awareness mechanism designed for users who access web-based collaborative systems using mobile devices. The limited capabilities of such devices (reduced display size, limited battery and memory capacity...) constitute intrinsic constraints which make even more tenuous the issue of delivering relevant information to collaborative mobile users. We propose here an object-based representation of the notion of context and an awareness mechanism which filters the available information according to both the physical (user's location and device) and organizational (knowledge relative to the collaborative process) contexts of the user.

Keywords. awareness, context-aware computing, mobile computing,
\end{abstract} collaborative systems.

\section{Motivations}

This work aims at providing an awareness support for Web-based collaborative systems, particularly those supporting asynchronous work. These systems can be accessed by webenabled mobile devices (PDAs, cellular phones...), and consequently exposed to the problems their use may cause [2]. The information overload problem addressed by awareness mechanisms [1] [4] embedded in collaborative systems, is made more accurate when using mobile devices due to their physical constraints (see [2]). For delivering some relevant information to mobile users involved in a collaborative task, one has to take into account not only their physical context (information about their location and the device they use), but also their organizational context (knowledge relative to the collaborative process). Existing works concerning awareness support do not integrate these two aspects of the user's context. We propose here a representation of the notion of context which includes both the physical and the organizational views of the user's context and we propose an awareness mechanism which exploits this representation for filtering adequately the information delivered to users.

\section{A Context-Based Awareness Mechanism}

We have designed an object-based representation of the notion of context [3] as a UML schema in which classes represent both the user's physical context (classes location, device, application) and the user's organizational context (classes group, role, member, calendar, activity, shared object and process). The context itself is represented by a class context description, which is a composition of these concepts. This UML schema has been implemented as a knowledge base using the java API of the object-based knowledge representation system AROM. This allows us to describe the context of a mobile user accessing the collaborative system. This awareness mechanism is built using a framework for awareness support called BW [4], which adopts an event-based model. In this model, all the awareness 
information delivered to the user is supported by events. Events are defined by the system developer and may contain any useful information about a specific topic related to the collaborative process. This process intends to determine, using the context representation, which events are relevant in the user's current context. The filtering process performed by the awareness mechanism is based on the concept of general profiles. General profiles represent the preferences and the constraints the system should satisfy for each context element (a member, a role, a device...). For instance, profiles of group members and roles describe the preferences of users performing some roles the awareness mechanism has to take into account. Thus, these profiles define the event types that should be delivered to the user and a priority order for them. A profile can be associated with a time interval which indicates when events must be sent. It can also be associated with some context conditions which describe which events must be sent. Profiles are classes of the knowledge base and are associated with context description. This association reflects that (i) events are produced in a certain context, (ii) each profile has a context in which it can be applied, and (iii) once a mobile user accesses the system, she/he is doing so through a specific context. The filtering process is performed in two steps. First, when a collaborative user logs, all the profiles which correspond to this user in the context of the application currently executed are selected. Then, the selected profiles apply. The first step is performed by comparing the content of the context description instances of both, the active user and the profile: if the context description instance of the profile has the same content or is a subset of the current user's context description instance, then this profile is selected. In the second step, the awareness mechanism compares the conditions associated with the selected profiles to the information carried by the available events. Among all events, the awareness mechanism selects only those which match these conditions. This matching is achieved as follows: for each selected profile, among the available events, those whose type corresponds to a type indicated in the profile are selected. If the profile is also labeled by a time interval, the algorithm restrains the selected events to those which have occurred (or should occur) in this interval. Then, it applies the context conditions, by checking, for each selected event, if its context description satisfies these conditions. If the event satisfies all conditions, it will be delivered to the user. Otherwise, the mechanism will discard it. At the end of this process, the user will receive a limited set of events, considered as relevant for her/his current context.

\section{Conclusions}

This paper has presented an awareness mechanism which uses an object-based context representation in order to perform a context-based filtering process. The adopted context representation was implemented using the AROM system (see [3]), and the filtering process was implemented using the BW framework [4]. We intend to improve the filtering process by refining the definition of the general profiles, as well as the definition of the subset relation.

\section{References}

1. Espinosa, A., Cadiz, J., Rico-Gutierrez, L., Kraut, R., Scherlis, W., Lautenbacher, G.: Coming to the wrong decision quickly: why awareness tools must be matched with appropriate tasks. CHI Letters, CHI 2000, vol. 2, n 1 . ACM Press (2000) 392-399.

2. Jing, J., Helal, A., Elmagarmid, A.: Client-server computing in mobile environment. ACM Computing Surveys, vol. 31, $\mathrm{n}^{\circ}$ 2. ACM Press (1999) 117-157

3. Kirsch-Pinheiro, M., Gensel, J., Martin, H.: Representing Context for an Adaptative Awareness Mechanism. To appear in X International Workshop on Groupware (CRIWG'04), San Carlos, Costa Rica, 05-09 Sept. 2004. Springer-Verlag (2004)

4. Kirsch-Pinheiro, M., Lima, J.V., Borges, M.R.S.: Framework for Awareness Support in Groupware Systems. Computers in Industry, vol. 52, n $^{\circ} 3$. Elsevier (2003) 47-57 